\title{
Glauco, guardião do lógos
}

\author{
Roberto Bolzani Filho \\ robertof@usp.br \\ Universidade Estadual de São Paulo (USP), São Paulo, Brasil
}

resumo Este texto pretende desenvolver a tese de que o principal interlocutor de Sócrates em A República, Glauco, irmão de Platão, revela qualidades semelhantes àquelas que serão exigidas dos guardiões e do futuro filósofo e governante da cidade construída na argumentação de Sócrates e seus interlocutores. Procura-se mostrar que isso pode ser encontrado em diversos momentos do diálogo. Pretende-se também extrair algumas consequências para a própria compreensão desse diálogo e da filosofia platônica como um todo.

palavras-chave Glauco; coragem; facilidade de aprender; memória; diálogo; educação

Os leitores atentos de $A$ República bem sabem que a substituição de Trasímaco, interlocutor de Sócrates até o fim do primeiro livro, por Glauco e Adimanto, dois novos interlocutores que permanecerão na função até o fim do diálogo, tem algum significado filosófico relevante. Isso é evidente já no ambiente mais pacífico que predominará após essa troca, que põe em segundo plano um sofista de temperamento irascível, para trazer sob os holofotes dois irmãos de Platão, costumeiros frequentadores de reuniões e conversas socráticas. Tal expediente deve ser visto como indício de uma alteração metodológica que permite nova e mais adequada formulação da questão central do diálogo. Até então influenciado pelo clima bélico a que o submeteu o sofista, Sócrates, embora o tenha de certo modo refutado, constata finalmente que a questão que debateram não poderia ser satisfatoriamente respondida, pois, para tanto, seria necessário que se desse solução a outro problema: não se pode descobrir 
se a justiça é saber e virtude, e se torna feliz quem a possui, em contraste com a pretensão de Trasímaco, de que mais vale ser injusto do que justo, sem antes conhecer o que ela é (354b-c). A questão inicial, a da definição da justiça, fora aos poucos nublada pelas efusões passionais de Trasímaco e transformada em outra, a que não se poderia responder adequadamente nessas condições.

Nessa alteração de personagens, que permite a retomada e reformulação, no início do livro II, da posição de Trasímaco, destaca-se a maneira como Glauco mostra a Sócrates por que é preciso repor a questão da justiça com base na tese trasimaquiana da justiça como interesse do mais forte. Glauco manifesta dúvidas sobre a forma pela qual Sócrates refutava Trasímaco, julgando-a semelhante a um encantamento (358b). Deixa claro a Sócrates que a discussão que se deu não o convenceu de nenhum dos dois lados (358b), pois não foi capaz de expressar o que seria a justiça em si mesma (358d). Assim, embora não creia que Trasímaco esteja com a razão, vai reformular sua tese, apresentando-a sob nova roupagem, para que Sócrates possa, agora, afastá-la adequadamente e, assim, seguir uma via adequada para a resposta à questão sobre a justiça. Embora não acredite nela, ele é capaz de apresentá-la com toda a sua força de persuasão, porque nisso vê a única forma de descobrir o que são em si mesmos justiça e injustiça (358c-d). Para isso, tendo inicialmente exposto uma divisão sobre tipos de bens (357b-358a), em seguida desenvolve toda a sua argumentação com base na relação entre natureza humana e lei (358e-362a), que, conferindo à posição do sofista razões filosóficas de peso, dará o tom de toda a investigação posterior e permitirá a solução da questão.

A partir dessa intervenção inicial do jovem interlocutor de Sócrates, trata-se aqui de analisar algumas outras passagens, nas quais se podem perceber traços de seu perfil intelectual, para formular uma tese, já levantada em alguns estudos sobre o diálogo, mas que certamente mereceria maior aprofundamento: essas passagens mostram que em Glauco se apresentam, ao menos em esboço, traços da natureza filosófica que o diálogo construirá e proporá como conditio sine qua non para a existência de uma cidade justa. Já sua capacidade de recuperar uma posição significativa a respeito do assunto em questão, embora contaminada pelo páthos de um sofista como Trasímaco, traduzindo-a agora para a boa linguagem filosófica - por assim dizer, compreendendo-a mais adequadamente do que seu próprio 
defensor -, somada a outras características, evidentes em suas intervenções ao longo da conversação, podem ser interpretadas como a presença já necessária, em certa medida, daquela potência filosófica que o diálogo mostrará ser, mediante a correta educação, a única forma de obter uma cidade justa e feliz. Ou, se essa afirmação for demasiado forte, poderemos ao menos dizer que, como interlocutor de Sócrates, ele exibe certas qualidades, perceptíveis em sua retomada da tese de Trasímaco e em vários outros momentos, que o tornam uma espécie de interlocutor necessário, o que pode significar que, agora, é preciso que Sócrates tenha um novo tipo de interlocutor, diferente dos que com ele travaram conversação em diversos diálogos considerados "socráticos" de Platão. Para defender tal tese, passemos em revista, ainda que um tanto sumariamente, a presença de Glauco no diálogo'.

$* * *$

Já no início do segundo livro, comentando a contundente intervenção que Glauco acaba de fazer, Sócrates o considera "sempre muito valente diante de todas as situações (aeí te andreiótatos... pròs hápanta)" $(357 \mathrm{a})^{2}$. Temos aí vocabulário importante e sugestivo, pois a construção da cidade ideal, a descrição dos guardiões e de sua educação levarão Sócrates e seus interlocutores a verem na coragem uma das virtudes fundamentais que permitirão estabelecer a cidade e o caráter do guardião e futuro filósofo que deverá governá-la. Os guardiões, diz Sócrates, não devem imitar, mas, se o fizerem, que sejam imitadores do que desde a infância lhes convém: dos temperantes, dos piedosos, dos homens livres e dos corajosos (andreíous) (395c). A cidade completamente boa, perfeita, será, por isso, "sábia (sophé) e corajosa (andreía), temperante (sóphron) e justa (dikaía)” (427e).

Embora talvez tenhamos aqui apenas uma coincidência terminológica, levemos adiante nossa comparação, observando a maneira como Sócrates define a coragem na cidade: esta é corajosa (andreía) porque possui uma parte capaz (dýnamis) de preservar (sósei) continuamente (dià pantós) a opinião sobre o que se deve temer (429b-c). A coragem é, portanto, uma espécie de preservação (sotería) (429c), uma capacidade e preservação (dýnamis kaì sotería) contínua da correta e legítima opinião (dóxa orthé) (430b), 
uma opinião "formada sob a ação da lei e por intermédio da educação" (429c), que a coragem mantém a salvo (diasózesthai), em meio a sofrimentos, prazeres, paixões ou temores, sem desfazer-se dela (kaì mè ekbállein)" (429c-d), como uma tintura indelével (429e-30a), cabendo à parte impetuosa (tò thymoeidés) preservar os ditames da razão (442b-c).

Atentemos agora para o que disse Glauco a Sócrates, quando declarou que iria reafirmar a posição de Trasímaco. Antes de expor o que os homens julgam ser a justiça e sua origem, e o motivo por que a seguem contra suas vontades, Glauco acrescenta: “A mim parece que não é assim... Não tenho, porém, o que dizer (aporô), porque nos meus ouvidos estão zumbindo as palavras de Trasímaco e de milhares de outros (akoúon Thrasimákou kai myríon állon); mas um discurso em defesa da justiça, que diga que ela é melhor que a injustiça, isso ainda não ouvi de ninguém, da maneira que eu quero (hos boúlomai). Quero ouvir (boúlomai akoûsai) um elogio pelo que ela mesma é (autò kath' hautó) e penso (oîmai) que de ti eu ouviria isso" (358c-d). Parece-nos razoável dizer que Glauco exibe aqui algo como aquela "capacidade de preservação da opinião reta”, em meio a todos os obstáculos, que Sócrates descreve como coragem. A maneira como Glauco parece resistir à tese que "enche seus ouvidos" pode ser, em boa medida, aproximada dessa descrição. Glauco não possui, segundo se apreende de suas próprias palavras, uma "opinião correta" sobre a justiça, no sentido em que isso ocorrerá na cidade justa, ainda a ser construída. Seu pedido a Sócrates para que faça a defesa da justiça indica que ele próprio necessita de algo que o auxilie a afastar a opinião corrente. Seria excessivo, de fato, simplesmente identificá-lo ao caráter corajoso que a cidade e o guardião deverão exibir. Contudo, é também inegável que ele demonstra notável resistência àquilo que a cidade vem insistentemente lhe propondo: uma visão da justiça, afinal, exatamente como a de Trasímaco e muitos outros que, como ele, defendem a tese de que mais vale ser injusto do que justo.

A resistência de Glauco é acompanhada de vontade de permanecer na justiça num sentido forte: ele quer a defesa da justiça como, em si mesma, superior à injustiça. Ele busca a preservação, para si mesmo, de uma convicção que lhe é cara e que ele ainda não é capaz de justificar, mas que soube manter, em meio a circunstâncias intensamente desfavoráveis. Nesse sentido, ele exibe as condições necessárias para a aquisição da coragem como uma virtude na cidade ${ }^{3}$. 
Assim, são manifestações da coragem de Glauco: 1) a afirmação, diante de Sócrates, de sua discordância em relação a Trasímaco, mas também em relação à maneira como o próprio Sócrates argumentou, a ponto de propor, contra suas próprias convicções, nova defesa da tese do sofista, para que, agora, Sócrates realmente a refute; 2) a capacidade de resistir a uma massacrante concepção "realista" de justiça, veiculada insistentemente na cidade, em favor de uma outra, que é também de Sócrates. São necessárias disposição e atitude corajosas para escapar incólume dessa deletéria cultura política, a ponto de querer o elogio da justiça em si mesma e ser capaz de defender a tese contrária sem o risco de a ela aderir. Levando-se em conta o diagnóstico extremamente pessimista que Sócrates emitirá, mais tarde, a respeito dos efeitos nefastos da educação ateniense e do abuso da dialética entre os jovens, que transformaram o que deveria ser efetivo exame da verdade em mero jogo de refutação (537e-539d), não surpreende que se refira à coragem de seu interlocutor superlativamente (andreiótatos), com ampla extensão (pròs hápanta) e como nele presente sempre (aê).

Talvez se possa, então, associar e aproximar a disposição de Glauco a uma qualidade indispensável ao futuro filósofo: a veracidade ou sinceridade (apseúdeia), ou seja, "a decisão consciente (hékontas eînai) de recusar toda mentira (tò pseûdos), sentindo ódio (miseîn) pela mentira e carinho pela verdade (tèn alétheian stérgein)" (485c)

Além disso, embora vigoroso (erroménos) (361d) em sua retomada da posição de Trasímaco, Glauco sabe que há uma forma melhor de dizer e, por isso, alerta Sócrates para que, se seu modo de falar agora parecer muito "rude" (agroikotéros), "não sou eu quem fala, mas os que, em vez da justiça, elogiam a injustiça" (361e). Sua rudeza, portanto, serve estrategicamente a seu objetivo e não expressa seu próprio estado de ânimo. Cabe lembrar que semelhante rudeza ou selvageria auxilia a distinguir entre naturezas filosóficas e não-filosóficas: “ao examinar se uma alma (psykhén) é filosófica ou não (philósophon kaì mé), observarás se, desde a infância, ela é justa e mansa (díkaia te kai hémeros) ou insociável e selvagem (diskoinónetos kaì agría)"; e esse defeito se liga a outros, que também devem ser relacionados a uma natureza não-filosófica:"uma natureza covarde e grosseira (deilêi kai aneleuthéroi phýsei) não participaria, pelo que se vê, da verdadeira filosofia (philosophías alethinês)" (486b), o mesmo valendo para "uma natureza sem afinidade com as musas e carente de graça (tês amoúsou te kai askhémonos 
phýseos)" (486d). Ora, bem ao contrário, Sócrates afirma que Glauco é mousikós, quando investigam quais seriam os melhores cantos e melodias para a educação dos guardiões (398e). É verdade que o termo é aí empregado em sentido mais estrito e técnico, relacionado ao domínio da arte dos sons, mas é claro também que há uma acepção mais ampla e relevante, pois só se é realmente mousikós, diz Sócrates, quando se é capaz de reconhecer e perceber, presentes por toda parte, virtudes como a temperança, a coragem, a liberalidade, a magnanimidade e outras afins, além de seus opostos (402c), e quando se ama aquele que reúne características belas na alma e aspecto exterior concordante com elas (402c-d). "O verdadeiro amor (orthòs éros), por natureza, ama a ordem e o belo (kosmíou te kaì kaloû) com temperança e harmonía (sophrónos te kaì mousikôs)" (403a).

Não se pode dizer de Glauco que ele preenche plenamente essa descrição, mas também não se pode deixar de reconhecer, com base em comentários do próprio Sócrates, que o jovem apresenta traços que dela o aproximam. Isso pode ser observado quando, no oitavo livro, durante a análise das distintas formas de governo e suas relações, Sócrates e Glauco se detêm na investigação do caráter timocrata. Então, repentinamente Adimanto se adianta e afirma: "Creio que, no gosto pelas disputas (héneká ge philonikías), ele está muito próximo de Glauco” (548d). Embora Sócrates admita essa possibilidade - "Nisso, talvez (Ísos... toûto ge)" -, imediatamente observa haver diferenças "por natureza" (pephykénai): o timocrata "deve ser mais arrogante (authadésteron) e menos afeito às musas (hypoamousóteron), sem deixar de amá-las (philómouson), todavia. Deve ser um bom ouvinte (philékoon), mas de forma alguma um orador (rhetorikón)... Gosta do poder e das honras (phílarkhos dè kaì philótimos), mas não julga que chegará ao governo recorrendo à eloquência ou a algo semelhante, e sim, graças aos feitos da guerra e à arte bélica, já que ama a ginástica e a caça" (548e-549a). Sócrates recusa-se a associar as características naturais de Glauco a esse retrato. E o perfil de seu jovem interlocutor vai sendo desenhado por ele em sutil contraste com o do timocrata. Com isso, Sócrates deixa fortemente sugerido que aquilo de que carece o timocrata se apresenta então em Glauco: com o tempo, aquele mostra não ser puro em virtude (eilikrinès pròs aretén), por lhe faltar "o melhor guardião (tôิ arístou phýlakos)", "a razão... mais a música (lógou... mousikêi kekraménou)" (549b). Se assim for, será precipitado simplesmente identificar em Glauco 
a alma timocrata, embora a timocracia seja o regime imediatamente abaixo da constituição da cidade ideal.

A ressalva de Glauco sobre sua peculiar e excepcional rudeza talvez revele, então, a posse de uma característica fundamental do guardião: um "modo de ser que seja brando e, ao mesmo tempo, muito impetuoso" (práon kaì megalóthymon éthos) (375c).

Há duas outras qualidades intelectuais e filosóficas que Glauco exibe com alguma frequência no diálogo: a capacidade rememorativa e a facilidade de aprender, ambas consideradas por Sócrates como necessárias para o guardião e futuro filósofo. Pois o filósofo deverá ser eumathés, de aprendizado fácil, e não dismathés, de aprendizado difícil; deverá ser também uma psykhè mnemoniké, uma alma de boa memória (486c-d; cf. tb. 503c-d).

Quanto à facilidade para aprender, pode-se dizer que Glauco revela possuir tal qualidade naquela retomada da tese de Trasímaco, no início do segundo livro, visto que, em certa medida, ela resulta de sua observação e análise do conteúdo do debate entre Sócrates e o sofista, agora por ele reformulado. Atento seguidor de uma atribulada e às vezes até mesmo pouco clara conversação, Glauco, ao retomar seu tema nuclear, reformula a posição a ser combatida, nela introduzindo elementos que permitirão à investigação desenvolver-se em nível conceitual superior. Assim, no primeiro livro, Sócrates, ao posicionar-se contra a tese de Trasímaco de que o justo é o vantajoso para o mais forte, afirma a Glauco: "Se existisse uma cidade de homens de bem, poderia muito bem acontecer que a disputa deles fosse para conseguir ficar fora do governo, como hoje é para assumi-lo; e aí ficaria evidente que realmente o verdadeiro governante (tôi ónti alethinôs árkhon), por sua natureza (péphyke), não tem em vista sua vantagem pessoal, mas a do subordinado" (347d). Sócrates aí como que prenuncia e adianta, muito sucintamente, aspecto fundamental do governante da cidade justa - pôr acima de seus interesses o interesse da cidade toda - e a necessidade de procurar uma "natureza" adequada a essa incomparável função. Mas a introdução da ideia de uma espécie de "natureza do verdadeiro governante" não pode prosperar, diante das 
dificuldades para dialogar com Trasímaco e em virtude do beco sem saída a que serão levados, como logo se descobrirá. E esse mesmo inevitável desfecho aporético, associado à desqualificação da tese de Trasímaco, aparenta deixar em segundo plano o fato de Sócrates, em sua argumentação decisiva, mobilizar a ideia de que a injustiça, sobrevindo "no íntimo de uma única pessoa" (en henî), nem por isso perde sua "capacidade" (dýnamis) e, "existindo no íntimo de uma única pessoa (en heni... enoûsa), creio, produzirá tudo que, por sua natureza (péphyken), produz" (352a). Sócrates não tardará a refinar esse vocabulário, referindo-se a "uma tarefa da alma" (psykhês... ti érgon) (353d), que lhe é própria (ídia): administrar, deliberar, governar. Assim, a alma tem uma virtude (aretén... tina psykhês) (353d), e essa virtude da alma é justiça, e o vício, injustiça (aretén... psykhês eînai dikaiosýnen, kakían dè adikían) (353e).

A aporia final, fazendo abortar uma investigação que parecia ter encontrado os melhores termos para se desenvolver, não impedirá, no entanto, que Glauco, propondo no início do segundo livro a recuperação da posição de Trasímaco, o faça assimilando e já mobilizando esse novo e sucinto quadro conceitual e teórico ${ }^{5}$, assim exibindo sua facilidade de aprendizado.

Retomemos então a intervenção de Glauco. De início, ele anuncia seu motivo: "Meu desejo é ouvir o que é a justiça e a injustiça e que capacidade (dýnamis) tem uma e outra quando estão no íntimo da alma (enòn en têi psykhêi) e mandar às favas os salários e as coisas que delas decorrem" (358b). Já se percebe o emprego da terminologia socrática, na formulação da questão. A seguir, o jovem comunica sua estratégia; para que Sócrates faça o elogio da justiça em si mesma, Glauco vai retomar a tese de Trasímaco, em nome dos que a endossam, expondo o que eles entendem por justiça e qual é sua origem, por que a praticam, e por que é razoável que o façam (358b-c).

Vejamos os passos da argumentação: "Segundo dizem, por natureza (pephykénai), cometer injustiça é um bem e sofrê-la, um mal, mas o sofrer injustiça se destaca mais porque o mal que há nela é maior que o bem que há em cometê-la. Sendo assim, quando os homens, uns contra os outros, cometem injustiça e dela são vítimas, ao sentirem o gosto de uma e outra coisa, se não são capazes (tô̂s mè dynaménois) de evitar uma e obter a outra, parece-lhes útil estabelecer um contrato que os proíba de mutuamente cometer injustiça e sofrê-la. Essa é a origem e a essência da justiça que fica 
entre o ótimo, cometer injustiça e não ser punido, e o péssimo, ser vítima de injustiça e não poder vingar-se. A justiça, estando entre esses dois extremos, é amada não como um bem, mas como algo que é honrado por falta de ânimo para cometer injustiça, pois quem pudesse (tòn dynámenon) fazer isso e fosse verdadeiramente um homem, nem mesmo com uma única pessoa estabeleceria uma convenção que o proibisse de cometer injustiça e de sofrê-la. Isso seria uma loucura de sua parte! Então, Sócrates, eis a natureza (phýsis) da justiça e sua origem (ex hôn péphyke), segundo o que se diz. Perceberíamos melhor que quem pratica a justiça só a pratica de má vontade, por incapacidade (adynamíai) de cometer injustiça, se imaginássemos algo como isso..." (358e-359b).

Pode-se assim interpretar a maneira como Glauco faz sua intervenção inicial no segundo livro como uma demonstração de sua capacidade de assimilação, análise e compreensão do debate que acaba de presenciar, dando-lhe continuidade justamente porque soube com ele aprender que não há como bem formular e investigar o problema da justiça e da injustiça, senão do ponto de vista da natureza humana, da alma e suas capacidades.

De passagem, observemos que se sugere, nessa intervenção inicial, que Glauco, com a divisão dos bens em três tipos - os que apreciamos em si mesmos, os que apreciamos por si mesmos e por seus resultados, e os que apreciamos apenas por seus resultados - como preparação para a formulação da questão (357b-d), demonstra uma capacidade de "dividir segundo gêneros (kat'eide diairoúmenoi)", que lembra aquela que Sócrates louvará no bom uso do dialogar (454a) - observe-se a expressão "terceira espécie de bem" (tríton...ê̂dos agathoû) em 357c - além de certa "visão de conjunto", por assim dizer, similar talvez, embora certamente apenas embrionária, à capacidade sinóptica que, mais tarde, será atribuída ao dialético $(537 \mathrm{c})^{6}$.

Outro momento relevante do diálogo para a compreensão da facilidade de Glauco para aprender é aquele em que Sócrates, no sétimo livro, precisa mostrar como o filósofo deve voltar sua alma ao pensamento e ao ser, partindo de situações e fatos presentes aos sentidos. Nesta importante passagem (523a e segs.), de relevância maior a qualquer tentativa de erigir uma epistemologia platônica, parece-nos que o diálogo, ao mesmo tempo em que estabelece um ponto fundamental de doutrina, exibe a habilidade do jovem interlocutor de Sócrates para acompanhar seu raciocínio e com ele aprender. Inicialmente confuso sobre a ideia socrática de que, entre as 
sensações, alguns itens conduzem à reflexão e outros não (523a-b), Glauco ouve as explicações de Sócrates: a consideração de sensações opostas, como quando os diferentes sentidos, encarregados de distintos tipos de sensação, nos apresentam os mesmos objetos como moles e duros, leves e pesados, grandes e pequenos, conduz a alma à perplexidade e nela desperta a necessidade do recurso à reflexão e ao raciocínio (523b-524d). Glauco agora compreende e Sócrates então lhe solicita que tire uma conclusão com base no que foi dito (ek tôn proeireménon... analogízou) (524e), agora a respeito do número e da unidade, o que mostra que Sócrates reconhece no jovem tal capacidade. Não tardará muito para Glauco concluir, sempre com o auxílio de Sócrates, que tal processo intelectual deve levar-nos a reconhecer "números que só podem ser pensados e não podem ser tratados de outra maneira" (526a), o que garante ao estudo dos números o poder de obrigar a alma a "usar só a inteligência para atingir a verdade em si" (526b).

Vê-se com isso que o jovem é interlocutor qualificado para a investigação sobre temas filosóficos mais profundos. Isso, aliás, já era claro, quando chegara o momento de estabelecer, na parte que encerra o quinto livro e dá início ao núcleo propriamente filosófico do diálogo, as distinções entre conhecimento (epistéme) e opinião (dóxa), entre o philósophos e o philódoxos, à luz de outra distinção, ainda mais espinhosa, aquela entre "coisas belas" (kalà prágmata) e "o próprio belo" (autò kállos), para caracterizar o filósofo como aquele que considera "que o próprio belo existe e é capaz de contemplar não só a ele, mas também às coisas que dele participam e não toma como o próprio belo as coisas que dele participam, nem as coisas que dele participam como o próprio belo" (476c-d). Comenta Sócrates: "De maneira nenhuma seria fácil se fosse explicar a outra pessoa...Tu, porém, creio, haverás de concordar neste ponto" (475e). De todos os presentes, é Glauco quem mostra maior capacidade para acompanhar e auxiliar Sócrates no exame de tão complexos assuntos ${ }^{7}$.

\section{$* * *$}

Sobre a capacidade de utilizar bem a memória, temos um aspecto extremamente importante do perfil de Glauco, não somente porque lhe cabe às vezes a tarefa de recordar aos presentes e ao próprio Sócrates 
determinadas conclusões anteriormente obtidas, como também porque se encontram em algumas de suas intervenções procedimentos sem os quais o próprio diálogo e algumas decisões e compromissos nele firmados estariam sob risco. A memória de Glauco, além de garantir à investigação que ela siga o bom caminho, isto é, que não perca de vista seu fio condutor, torna-se garantia de preservação do próprio dialogar como meio de investigação. A memória de Glauco é "guardiã” do diálogo enquanto método.

De fato, Sócrates confia na memória de Glauco e a evoca em momentos decisivos da marcha argumentativa. No início do oitavo livro, encerrada a elaboração da figura do filósofo-governante e sua educação, Sócrates retoma alguns pontos anteriores: comunidade de mulheres e filhos, governo do filósofo, bens comuns dos guardiões. "Mas estou bem lembrado (allà mnemoneúo)", diz Glauco, fazendo em seguida alguns acréscimos considerados corretos por Sócrates (543a-b). A seguir, Sócrates lhe solicita auxílio: "procuremos lembrar-nos (anamnesthômen) onde começamos o desvio que nos trouxe aqui, para que retomemos o mesmo caminho" (543c). Glauco, imediatamente e com facilidade - "isso não será difícil (ou khalepón)"-, refaz esse trajeto: "Há pouco, quando acabaste de falar sobre a cidade, quase ias dizendo que considerarias boa uma cidade que fosse como a que tinhas descrito naquela ocasião e como bom o homem que fosse semelhante a ela, e isso, ao que parece, embora pudesses falar de uma cidade e de um homem ainda mais belos. Mas, se essa constituição é boa, tu dizias, as outras são defeituosas. Pelo que me lembro (hos mnemoneúo), afirmaste que, entre as outras formas de constituição, quatro mereceriam que as levássemos em conta... E, no momento em que eu te perguntava que constituições eram essas quatro, Polemarco e Adimanto tomaram a palavra, e foi assim que, acolhendo a pergunta deles, chegaste a este ponto" (543c-544b). Resta a Sócrates reconhecer:"Fizeste uma rememoração muito precisa (orthótata... emmnemóneusas)" (544b). Aqui, a boa memória do jovem colabora com Sócrates para a retomada do caminho que a investigação deve trilhar.

Além disso, se Sócrates, em certas ocasiões, recorda seus interlocutores, inclusive Glauco, de algo que parecem ter esquecido, como se os corrigisse, há situações em que o inverso ocorre. Por exemplo, no sétimo livro, introduzindo o tema da educação do futuro filósofo-governante e indagando sobre que tipo de aprendizado teria o poder de dirigir a alma para 
o ser, Sócrates inicialmente menciona a música, o que provoca a seguinte reação de Glauco: "Mas, se estás lembrado (ei mémnesai), ela é a contraparte da ginástica... Forma os guardiões com os hábitos, propiciando-lhes, com a harmonia, um temperamento harmonioso, não uma ciência, e, com o ritmo, o senso do bom ritmo, tendo nos outros discursos, quer míticos, quer verdadeiros, alguns outros hábitos semelhantes. Um ensinamento, porém, que leve a um fim como o que agora buscas, nela não há nenhum”. A isso responde Sócrates: "Fazes que eu me lembre muito nitidamente (akribéstata... anamimnéskeis me)... Realmente ela não tem tal capacidade" $(522 \mathrm{a}-\mathrm{b})^{8}$.

É preciso ainda observar que a boa memória de Glauco se associa a certa atitude ou disposição, frequentemente exercitada por ele, de evitar a todo custo que Sócrates tergiverse ou, por alguma razão, se abstenha de executar tarefa antes assumida. No quarto livro, no momento em que se encerra a construção em lógos da cidade procurada e diante da exortação de Sócrates para que todos o auxiliem na procura da justiça na

cidade recém-fundada, Glauco observa: "O que falas não faz sentido (oudèn légeis)!... Prometestes que tu mesmo haveria de fazer essa pesquisa, alegando que, de tua parte, seria uma impiedade se não acorresses em socorro da justiça usando a força e meios que tens". Sócrates reconhece que a lembrança de Glauco é verdadeira (alethê... hypomimnéskeis), sem deixar de reiterar seu pedido de auxílio, com o qual todos concordam (427d-e).

Um dos exemplos mais significativos desse papel por assim dizer metodológico exercido pelas intervenções de Glauco e sua memória, é certamente uma passagem do quinto livro, preparatória para a afirmação da tese central do diálogo, a da necessidade do governo do filósofo para a justiça da cidade (473d-e). Com certa ousadia que lhe é própria e interrompendo um raciocínio de Sócrates, Glauco afirma: "Mas, Sócrates, parece-me que, se permitirmos que fiques falando coisas semelhantes, jamais te lembrarás (mnesthésesthai) daquilo que até agora, em tudo que falaste, deixaste de lado... Essa constituição é possível? De que modo ela será possível?... Vamos! Já que admito que haveria todas essas vantagens e mil outras, se a constituição fosse essa, não fales mais a respeito dela! Ao contrário, tentemos já convencer-nos a nós mesmos de que isso será possível e como o será, dizendo adeus a tudo o mais" (471c-e $)^{9}$. O jovem ouvirá então de Sócrates que, quando souber a resposta, entenderá 
tamanha hesitação, mas isso não é suficiente para evitar que Glauco reaja: "Quanto mais ficares falando coisas assim, menos liberdade te daremos de te negares a dizer como será possível que venha a existir essa constituição. Vamos! Fale e não percas tempo!" (472a-b).

Glauco se mantém vigilante. Diante da tarefa de estabelecer a polêmica tese de que as mulheres e filhos serão comuns aos guardiões - "nem o pai conhecerá seu filho, nem o filho a seu pai” (457d) -, Sócrates se propõe a discutir se isso é possível, deixando de lado a justificação dos benefícios dessa ideia. Ao ouvir sobre a intenção de Sócrates de evitar o segundo ponto, diz Glauco: "Mas não conseguistes fugir sem que percebêssemos...Vamos! Dá conta do teu recado (dídou lógon) em ambos os casos!" (457e). Sócrates acata a ordem e se submete, chegando mesmo a solicitar a Glauco que lhe permita abordar essas questões supondo inicialmente resolvida uma delas. A esse pedido o jovem responde afirmativamente e ordena: "Faze teu exame (skópei)" (458a-b) ${ }^{10}$.

Sócrates parece ter encontrado em Glauco um companheiro de investigação que compreende a importância desse tipo de questão. Assim, no final do quarto livro, chega-se ao problema levantado por Glauco no início do segundo livro e agora retomado: "se também é útil praticar atos justos, ocupar-se com o que é belo e ser justo, quer os outros tomem conhecimento disso, quer não, ou se é útil cometer injustiça e ser injusto, caso não seja punido nem se torne melhor por ter sido castigado" (445a). Perante o comentário de Sócrates de que "não devemos desistir" (ou khrè apokámnein), Glauco é incisivo: "De forma alguma, por Zeus! Desistir nunca (hékista... pánton apokmetéon)" (445b). Essa atitude tenaz e decidida se observa também no momento em que, no quinto livro, tendo que abordar o dificil tema da comunidade de mulheres e filhos, que desperta muita incredulidade, Sócrates hesita diante da solicitação dos presentes para que não o adie mais, e afirma que se trata de assunto muito extenso. A isso responde Glauco:"Ora, para ouvir tais discussões, Sócrates, quando se tem senso (noûn ékhousin), a medida (métron) é a vida toda (hólos ho bíos).Vamos! Deixa de lado o que só a nós diz respeito... Quanto a ti, porém, não desistas (medamôs apokámnes) de expor tua opinião a respeito das questões sobre as quais te interrogamos!" (450b). Neste passo, é como se Glauco advertisse o próprio Sócrates sobre a prescrição feita pouco antes: "não devemos desistir". 
A afirmação do jovem deve ser compreendida em toda a sua intensidade: trata-se, a bem dizer, de uma verdadeira profissão de fé filosófica, bem à maneira socrática, chegando a evocar, em seu espírito, a missão divina da Apologia, que põe acima de tudo a busca do saber e o exame crítico da sabedoria apenas presumida. Não haverá assunto, por mais complexo e obscuro que seja, a ser evitado, sobretudo se diz respeito àquilo "que toda alma busca e é objeto de todas suas ações" (505e), o bem: "Por Zeus! Sócrates, não te vás como se tivesses chegado ao fim! Para nós será suficiente que faças uma exposição sobre o bem como já fizeste sobre a justiça, a temperança e outras virtudes” (506d). Glauco aceita que Sócrates fale do "próprio bem" (autó... tagathón) por meio de seu "filho", a ele semelhante - o sol - (506e) e, mais tarde, diante da elevação até bizarra do resultado e da reserva de Sócrates sobre suas próprias opiniões, acrescenta: "E de maneira nenhuma deixas de expô-las. Se não quiseres dizer algo, retoma a comparação relativa ao sol, caso algo esteja faltando... Não omitas nada, por pequeno que seja" (509c) ${ }^{11}$.

Glauco, assim, expressa sua plena adesão e compromisso com o diálogo como exame da verdade. Num momento complexo da investigação, em meio ao exame das ciências propedêuticas à dialética, Sócrates, ciente das dificuldades relativas a um assunto tão afastado da mentalidade comum, pede a seu jovem interlocutor que decida sobre como procederá, contanto que seja capaz de "construir teus argumentos pensando em ti mesmo, sem que sintas inveja de um outro". Ele não hesita: "Eis minha escolha (airoûmai)... Pensando principalmente em mim mesmo (emautoû héneka tò pleîston), vou falar perguntando e respondendo (kaì erotân kaì apokrínesthai)" (528a). Ele parece endossar uma concepção de diálogo, segundo a qual é preciso possuir uma atitude adequada, uma disposição específica; e não se furta, para encorajar Sócrates, a afirmá-la: "Nada de hesitação! Aos teus ouvintes não falta nem discernimento (oúte agnómones), nem confiança (oúte ápistoi), nem boa disposição (oúte dýsnoi)" (450d).

\section{$* * *$}

O que esse breve exame pode dizer-nos de filosoficamente relevante para a compreensão do diálogo? O que ganhamos, com isso, para nosso 
conhecimento do chamado "platonismo"? Tentemos então apontar para algumas conclusões.

Os leitores atentos de $A$ República têm observado, com razão, que durante o diálogo Glauco e Adimanto são educados por Sócrates, de forma a voltarem-se para uma vida guiada pela filosofia ${ }^{12}$. Evitam assim os perigos de um excessivo amor pela honra, típico da aristocracia ateniense, e que, se bem orientado, poderá produzir benefícios, como no caso de Glauco, que, dotado de boas qualidades, representa em esboço o retrato do guardião da cidade justa ${ }^{13}$.

Como vimos, as mesmas qualidades que permitem ver em Glauco um guardião da cidade, tornam-no também um guardião desse lógos que ele, em primeiro plano, mas também Adimanto e seus companheiros, em menor medida, vão gradativamente desdobrando, sob a direção de Sócrates, pela via do diálogo. Sempre atento aos argumentos socráticos, criticando, quando necessário, o procedimento de seu interlocutor maior, Glauco se torna "um estímulo precioso, portanto, para a superação ou ao menos para o esclarecimento de algumas das maiores dificuldades teóricas encontradas ao longo do percurso da República"14. Mas isso só foi possível porque ele soube escapar do frequente equívoco que a cidade comete a respeito da dialética. Como observa Sócrates, explicando a resistência comum ao bom uso do discurso, praticada por jovens despreparados e ávidos de bajulação, ela se torna um brinquedo, empregado para a refutação desenfreada, que faz apenas neles produzir o descrédito sobre as verdades antes sustentadas e, consequentemente, sobre a filosofia como um todo (537e-539d). Isso leva a que muitos julguem dialogar (dialégesthai), quando, na verdade, estão apenas a disputar (erízein) e contradizer, preferindo a antilogia ao autêntico diálogo (454a). Nisso, nosso jovem se posiciona no extremo oposto de interlocutores socráticos irascíveis, como Trasímaco, porque, ao contrário dele, possui natureza filosófica (phýsis philósophos) ${ }^{15}$. Esse sofista, aliás, parece ser, de fato, apenas o representante mais furioso de um grupo de interlocutores que inclui outro sofista, Protágoras, no diálogo de mesmo nome, e Polo e Cálicles, no Górgias. Todos eles, cada um a seu modo, parecem comungar da ideia de que o diálogo, como o pugilato, nada mais é do que uma disputa que se deve vencer, a todo custo e com os meios que se fizerem necessários ${ }^{16}$.

Por tudo isso, além de alvos da educação proposta no diálogo e, portanto, governantes em potência da boa cidade, os dois irmãos - sobretudo 
Glauco - são interlocutores necessários de Sócrates, que não mais pode fazer evoluir a investigação sem o seu auxílio. Nesse sentido, pode-se também concluir que o sucesso da procura pelo correto perfil intelectual do guardião e do governante necessita que tal perfil intelectual, nalguma medida, se manifeste nessa procura. Para que o diálogo alcance seus objetivos, seus participantes, beneficiados e educados por seus efeitos, devem exercer, junto com o mestre, papel protagonista, efetivamente influindo na marcha do lógos, talvez quase tanto quanto o próprio Sócrates. Nesse caso, é como se a pintura do retrato do filósofo consistisse também na descoberta, pelo interlocutor, de que esse retrato se refere a ele próprio. Isso os torna, ao mesmo tempo, interlocutores ideais ${ }^{17}$.

Temos, então, dois planos de significado do diálogo, que proporcionam dois pontos de vista para sua compreensão, sem, com isso, deixarem de exercer colaboração recíproca: um plano doutrinal, no qual o filósofo elabora teses e argumentos a respeito do que seria uma cidade boa, justa e feliz, fazendo sua defesa contra mentalidades políticas contrárias às suas posições. Trata-se aí, sobretudo, de informar, provar, persuadir em favor de certas teses e desqualificar certas outras, por meio de argumentos, que pedem ao leitor análise rigorosa segundo critérios de natureza lógica. E um plano educativo, no qual caracteres são elaborados em consonância com o conteúdo das teses defendidas ou recusadas, e atitudes e posturas intelectuais, também associadas a tais teses, são exercitadas, incentivadas, louvadas ou criticadas. Trata-se então, sobretudo, de formar, de exortar, coordenando o conteúdo das teses e argumentos ao elogio do diálogo como via adequada de investigação e como atividade constante e permanente de interrogação, crítica e autocrítica. Aqui, cabe ao leitor dirigir a atenção - como se tentou neste breve estudo - a sutis observações, talvez desnecessárias para o bom estabelecimento e para a compreensão dos argumentos, mas ricas em indicações a respeito do caráter filosófico elaborado no decorrer do diálogo e de seus contrapontos.

Ora, haverá talvez um terceiro enfoque, relacionado aos anteriores, pelo qual se deverá olhar para Glauco e Adimanto: eles seriam também a construção dos leitores ideais do diálogo, isto é, de seus destinatários. A República, então, terá sido escrita para jovens $\operatorname{como} \operatorname{eles}^{18}$, e espírito e letra do diálogo, para serem bem compreendidos, exigirão um leitor de natureza filosófica, leitor que essa mesma escrita quer atingir, ensinar e atrair. A 
seleção, no interior do diálogo, dos guardiões e filósofos da cidade ideal é também a seleção de um interlocutor sem o qual não há diálogo e, agora, a seleção de um leitor que habita uma cidade que tem muito pouco, ou quase nada, das qualidades ideais e necessárias, e que, como nos descreve o sexto livro (487b-497a), vem corrompendo as verdadeiras naturezas filosóficas que abriga.

Se assim for, julgamos que poderá haver, para os leitores de $A$ República e dos diálogos platônicos como um todo, um ganho e uma tarefa, decorrentes de uma análise do papel de Glauco no diálogo. O ganho: se Platão, com a paradigmática figura de Glauco, se dirige aos jovens contemporâneos dotados das adequadas qualidades filosóficas, com o objetivo de neles despertar ou recuperar uma inclinação natural que a cidade vem inibindo e até destruindo, tem-se pelo menos uma via para pensar a questão do aparentemente paradoxal caráter mimético desses diálogos. A mímesis seria, nesse caso, um expediente necessário e talvez mesmo indispensável para expressar e esclarecer a boa filosofia nessa cidade ${ }^{19}$. Consequentemente, impõe-se uma tarefa: pensar, para os diálogos, algo como uma "teoria da recepção", ou uma "estética da recepção". Não se poderiam justificar certos expedientes neles presentes como instrumentos dramáticos e literários, agora a serviço da verdade, para alcançar com sucesso seus seletos leitores?

Nesse sentido, a profundidade filosófica e o talento literário de Platão talvez encontrem um meio de conciliação.

\footnotetext{
${ }^{1}$ Apenas a título de introdução e na medida do necessário, o dito acima faz alusão a análises desenvolvidas em outro texto, intitulado "A retomada da tese de Trasímaco no segundo livro de A República", a ser publicado. No que segue, tentar-se-á desdobrar um pouco mais a ideia central daquele texto, pensando-a para o diálogo como um todo e do ponto de vista de algumas de suas teses centrais.

${ }^{2}$ Adotamos, salvo indicação em contrário, a tradução em PLATÃO 2006. A edição do texto grego é a de E. Chambry, Coleção Budé.

${ }^{3}$ Desse ponto de vista, pode-se associar a atitude de Glauco à concepção de conhecimento a ser formulada e analisada no Teeteto: conhecimento (epistéme) é opinião verdadeira (alethès dóxa) acompanhada de justificação (metà lógou) (201c-d). Seria ir longe demais afirmar que a encontramos plenamente pensada e pressuposta na fala de Glauco, mas não o será observar, ao menos, que o jovem interlocutor de Sócrates é movido por certo ideal cognitivo, compatível com aquela definição. O mais importante, no entanto, é notar que tal aspiração a uma
} 
justificação pressupõe sua capacidade corajosa para permanecer voltado à satisfação desse ideal, num meio francamente desfavorável a isso.

${ }^{4}$ Ainda que de forma apenas embrionária, valerá talvez para Glauco o que diz respeito àquele que será educado na filosofia: "nenhuma lição o homem livre (tòn eleútheron) deve aprender como se fosse um escravo. Se os trabalhos do corpo, mesmo quando exercidos sob coação, em nada prejudicam o corpo, para a alma nenhum aprendizado é duradouro se imposto à força (psykhêi dè bíaion oudèn émmonon máthema)" (536e). A observação é geral, mas talvez ilustre a reação à tese de Trasímaco, expressa no início do segundo livro, compartilhada por muitos e constrangedora a Glauco.

${ }^{5}$ Salvo engano, o vocabulário da phýsis, da dýnamis, da areté e da psykhé aparece apenas nas passagens citadas, a partir de $347 \mathrm{~d}$.

${ }^{6}$ Como observa Vegetti, o emprego da expressão autò kath' hautó em 358d - presente também em 358b - "enfatiza o esforço de Glauco para uma crescente abstração e conceptualização da discussão sobre a justiça”" (VEGETTI, 1998, p. 27, n. 7). A aproximação com qualidades filosóficas como a visão de conjunto típica do dialético deve, evidentemente, ser proposta cum grano salis. Em nenhum momento, aqui, se trata de afirmar que Glauco é filósofo, mas sim que apresenta, em sua natureza, qualidades que o tornam um guardião e um filósofo possível, na cidade construída em lógos.

${ }^{7}$ A mesma facilidade, Glauco a demonstra quando expressa as diferenças entre a dialética e as outras ciências, após a divisão da linha no sexto livro, assimilando rapidamente a terminologia empregada por Sócrates: "princípio" (arkhê), "hipóteses" (hypothéseis), "pensamento" (diánoia), "inteligência" (noûs). Sócrates comenta: "Entendeste de modo mais que suficiente (hikanótata... apedéxo)" (511c-d).

${ }^{8}$ Em 465e-466a, Sócrates pergunta a Glauco: “Estás lembrado (mémnesai)... de que num certo momento de nossa discussão uma pessoa, eu não sei quem (ouk oîda hótou logos)... me censurou dizendo que não tornamos felizes os guardiões que, embora pudessem ter tudo que os cidadãos possuem, nada têm?" "Estou lembrado (mémnemai)", responde Glauco. Aqui, ressalta-se a memória do jovem, ao mesmo tempo em que, por meio de Sócrates, indica-se a importância menor de recordar quem proferiu certa tese (no caso, Adimanto), em favor de recordar seu conteúdo, importante que é para o desenvolvimento da investigação.

${ }^{9}$ No que será talvez outra manifestação de sua facilidade para aprender, ao fazer esse chamamento à ordem, Glauco não deixa de desenvolver a própria posição de Sócrates sobre os benefícios da nova cidade: "Eu ainda cito vantagens que estás omitindo (hà sù paraleípeis egò légo)... E em tempo de paz? Vejo vantagens que eles teriam e que foram deixadas de lado (hà paraleípetai agathá, hósa àn eíe autô̂s, horô)" (471c-d).

${ }^{10}$ Logo a seguir, iniciando a análise, Sócrates diz a Glauco: "Pois bem! Tu, legislador que és... (sú... ho nomothétes)" (458c). Trata-se, ao mesmo tempo, de indicar que Glauco colabora com Sócrates na construção discursiva e argumentativa da boa cidade, e de sugerir ao leitor que é a jovens como Glauco que caberia a função primordial na cidade, a do governante. No mesmo sentido se pode e deve interpretar a alternância entre as expressões "a nossa cidade" (epì tèn hemetéran pólin) (462e) e "a tua cidade” (soi tês póleos) (461e), que Sócrates usa com Glauco.

doispontos, Curitiba, São Carlos, vol. 10, n. 2, p.11-32, outubro, 2013 
${ }^{11}$ Em momentos como esse, o conteúdo e o tom da intervenção de Glauco soam tipicamente socráticos. Exortações dessa natureza são frequentes, nos diálogos, na boca de Sócrates, diante de interlocutores reticentes ou desnorteados, o que mostra que Glauco desempenha um papel mais do que coadjuvante aqui, chegando mesmo, em alguns momentos, a assumir a função de condutor da conversação, como no início do oitavo livro, ao rememorar para Sócrates como se deu o desvio da linha inicial de argumentação e, em seguida, exortá-lo: "Pois bem! Como um pugilista, retoma a mesma posição em que estavas e, quando eu te fizer a mesma pergunta (tò autò emoû eroménou), tenta dizer-me o que ias dizer naquele momento!” (544b). Glauco é também cauteloso ao assumir opiniões próprias (cf. p. ex. 398c), mostrando-se observador penetrante do comportamento infantil (441a), das relações entre homens e mulheres (455d, 458d) e, sobretudo, na importante investigação sobre quem são verdadeiramente filósofos, a respeito daqueles que apenas aparentemente o seriam: "Ah! Haverá muitas pessoas estranhas com tal disposição... Os que gostam de espetáculos são todos assim, na minha opinião, já que se aprazem com o aprender; os que gostam de ouvir são estranhos demais para que os coloquemos entre os filósofos, porque de livre vontade não procurariam ouvir discursos e uma tal conversa, mas, como se tivessem alugado seus ouvidos, circulam pelas Dionísias para ouvir todos os coros, sem perder nem as urbanas nem as rurais. Então, de todos esses e de outros como esses, que são inclinados a aprender, e também de artistas de pequena importância, afirmaremos que são filósofos?" (475d-e). Não será então despropositado associar este senso de observação a certas qualidades exigidas dos filósofos, que devem ser "perspicazes" (agkhínoi) e “vivazes” (óxeis) (503c).

${ }^{12}$ Segundo A. Bloom, “em República, Sócrates discute o melhor regime, um regime que nunca pode ser realizado, com dois jovens de certo talento teórico, que ele tenta converter, da vida de ambição política, para aquela em que a filosofia é atuante" (BLOOM, 1991, p. xx). Essa educação, como bem comenta Bloom, se dá pari passu à construção da cidade: "Sócrates leva Glauco e Adimanto aos limites da política e é nesses limites que se pode ver a natureza e os problemas da política.Aprendemos que a justiça é uma questão política: pode haver um regime cujas leis são tais, que sirvam ao bem comum, permitindo embora a cada um de seus membros alcançar sua perfeição natural? Senão, a vida será para sempre dividida entre o dever à cidade e o dever a si próprio. Fazendo o papel de fundadores, Glauco e Adimanto descobrem de uma vez que devem cuidar da justiça. Ao menos nesse caso, a satisfação de seus desejos é idêntica à preocupação com a justiça" (p. 343-4).

13 “A razão do privilégio concedido a Glauco consiste no peculiar perfil intelectual e moral que Platão atribui à figura de seu irmão. Glauco é um jovem naturalmente de origem nobre comprovada (368a, 357a); dotado, portanto, daquele thymos guerreiro, daquela philonikia não desprovida, no entanto, de gosto pela cultura (VIII 548d-e), portanto mousikos (398e1), que o torna um personagem da natureza 'timocrática', como é próprio da melhor aristocracia ateniense, e, portanto, também um ótimo candidato ao papel de 'defensor' (phylax) da futura cidade" (VEGETTI, 1998, p.151). Embora acerte ao considerar Glauco um guardião em potência, o comentário nos parece excessivo, quando nele vê a natureza do timocrata, pois, como vimos, Sócrates recusa a ideia, proposta por Adimanto (548d-549b). O ponto é bem observado por Ferrari, que contrasta o comentário de Sócrates nessa passagem com um trecho dos Memorabilia de Xenofonte (III, 6), onde Glauco parece assemelhar-se a um timocrata (FERRARI 2003, p. 13). Também são interessantes suas observações sobre a noção de philotimía, traduzível por "amor pela honra" ou "ambição", porque permitem pensar num sentido

doispontos, Curitiba, São Carlos, vol. 10, n. 2, p.11-32, outubro, 2013 
em que Glauco pode ser tomado como semelhante ao timocrata, sem, contudo, ser idêntico a ele. Ferrari recorre ao clássico estudo de K. Dover sobre o vocabulário moral da época, para dele tomar a distinção entre um sentido negativo e pejorativo, segundo o qual a philotimía remete ao que Ferrari chama "autoafirmação agressiva", e um outro sentido, uma espécie de "patriotismo" que bem se poderia associar ao guardião e a Glauco (cf. p. 22-3). Dover observa o emprego fortemente negativo, em Tucídides (II 65, 7), da expressão hai ídiai philotimíai - algo como "as ambições individuais" -, associada a ídia kérde, "ganhos individuais", além de outras passagens (DOVER 1994, p. 233), em contraste com a ideia de "patriotismo".

14 (VEGETTI, 1998, p. 153).Vegetti se refere a Glauco também como "valoroso aliado, mas também crítico desencantado e rigoroso" de Sócrates (p. 154). Não vemos, no perfil de Glauco, tal "desencanto".

15 O vocabulário da "natureza", phýsis, no sentido de um "caráter" ou "modo de ser", éthos, não é raro no texto, na descrição do guardião e do filósofo - cf. e.g. 375c-e, 376a.

${ }^{16}$ Para a ideia do diálogo como pugilato e combate, no Protágoras, cf. 335a, 339e. Glauco, como vimos, usou a imagem, mas sem nenhuma intenção bélica. Para a resistência e mesmo hostilidade de Cálicles e Trasímaco ao dialogar no espírito socrático, cf. respectivamente Górgias, 489b-c, 494d-495b, 497c, 499b-c, e República, 338d, 340d, 341b, 342d, 345b. De outro lado, pode-se encontrar outro caso de natureza filosófica em Teeteto, no diálogo de mesmo nome, como bem observa e comenta M. Boeri: "a construção que Platão faz da personagem Teeteto é simplesmente magistral. Em muitos sentidos se pode dizer que Teeteto, à época um jovem entre quatorze e dezesseis anos, é apresentado como alter ego intelectual e humano de Sócrates. As qualidades que Teeteto reúne são comparáveis às que Platão exige dos guardiões completos da pólis na República: tem facilidade para aprender, agudeza, boa memória e valentia (veja-se 144a-b)... é nobre ou extraordinário quanto a seu caráter (144d), é dócil, procede em suas lições com placidez e sem tropeços (144b)... admite sua própria ignorância sem que isso signifique um problema para ele $(148 \mathrm{~b} ; 148 \mathrm{e})$, manifesta seu interesse por preservar a coerência de seu discurso (154c-e) e compartilha o estado de perplexidade (aporía) próprio de Sócrates e que caracteriza a atitude filosófica (174c-d; 175b; 187d; 190e)" (BOERI 2009, p. 260). Sobre o compromisso com o diálogo: "A atitude de Teeteto a respeito do diálogo filosófico pode ser descrita como uma espécie de processo que vai in crescendo, de um compromisso menor com a conversação até outro, muito maior" (p. 263). Assim, o Teeteto "pode ser considerado como um diálogo no qual se apresenta o desdobramento efetivo do processo de educação filosófica de um jovem com os talentos naturais apropriados para tal processo de educação” (p. 264).

17 Isso decerto vale para Glauco e talvez valha, em menor medida, para Adimanto, embora isso não seja óbvio. O perfil filosófico do irmão de Glauco não é tão facilmente reconhecível durante o diálogo. A questão mereceria aprofundamento, embora esse não seja um dos objetivos desta análise.

${ }^{18}$ Concordamos com o comentário de J. Lear: "É importante ter em mente a quem a alegoria da Caverna se endereça. É ostensivamente endereçada a Glauco e Adimanto e é diretamente endereçada a eles... Suspeito de que, desse modo, a caverna é endereçada ao leitor ideal da República. Pois, como vimos, Glauco e Adimanto são pessoas excepcionalmente distintas que tiveram a infelicidade histórica de nascer em uma sociedade má. A República é um livro para pessoas assim" (LEAR, 2006, p. 36). "Se a kalípolis algum dia vier a ser estabelecida, terá de 
sê-lo por alguém como Glauco, embora mais bem posicionado em termos de poder e oportunidade histórica" (p. 37).

${ }^{19}$ Retome-se a já aludida passagem dos Memorabilia (III, vi, 16-7), na qual Sócrates mostra a Glauco que ele não possui ainda os conhecimentos suficientes para se destacar na cidade e pretender governá-la: "Cuida (phyláttou)", diz Sócrates a Glauco, "pra que, desejando ter boa reputação (eudoxeîn epithymôn), não caias no extremo oposto. Ou não vês como é arriscado dizer e fazer aquilo que não se sabe (tò hà mè oîdé tis, taûta è légein è práttein)? Pensa nos outros, e sabes como eles são, que aparecem dizendo e fazendo coisas que não sabem (phaínontai kaì légontes hà mè ísasi kai práttontes): parecem-te encontrar mais elogio do que censura e serem admirados mais do que mal vistos? E pensa também nos que sabem o que dizem e fazem (tôn eidóton hó ti te légousi kaì hó ti poioûsi) e constatarás, como julgo, que os que são em todas as ações célebres e admirados (en pâsin érgois toùs mèn eudokimoûntás te kaì thaumazoménous) estão entre os que mais conhecem (ek tôn málista epistaménon) e os que têm má reputação e desprezados (toùs dè kakodoxoûntas te kaì kataphronouménous) estão entre os que mais ignoram (ek tôn amathestáton). Se então desejas (epithymeîs) ter reputação e ser admirado na cidade (eudokimeîn te kaì thaumázesthai en têi pólei), tenta adquirir o melhor possível (hos málista) conhecimento do que queres fazer (tò eidénai hà bouléi práttein); se te esforças por agir na cidade distinguindo-se dos outros nisso, eu não me surpreenderia se muito facilmente alcançasses o que desejas" (XENOFONTE, 1997). Aqui, Glauco se aproxima de um ambicioso "timocrata" que recebe os conselhos de um Sócrates sábio, o qual procura convencê-lo da necessidade do verdadeiro conhecimento para a aquisição de boa reputação. Decerto não há incompatibilidade entre o que se atribui aí a Glauco e o retrato traçado em A República, mas pode-se concluir que estamos diante de duas distintas elaborações apenas verossímeis - miméticas, portanto. Disso, parece-nos, nenhuma conclusão sobre como era realmente Glauco, o meio-irmão de Platão, deve ser extraída. Mas o que importa é notar que, em ambos os casos, a construção da personagem Glauco serve a distintas intenções.

\section{Referências bibliográficas}

BLOOM,A. 1991. The Republic of Plato (2a. ed.). New York:

HarperCollins.

BOERI, M. 2009. “Filosofia y drama en el Teeteto de Platón”. In: MOTTA,A. C. \& ZAMORA, J. M. Eúnoia - Estudios de filosofía antigua - Un homenaje a María Isabel Santa Cruz. Bogotá: Univ. Nacional de Colombia.

DOVER, K. J. 1994. Greek Popular Morality in the time of Plato and Aristotle. 2a ed. Indianapolis/Cambridge: Hackett Publishing Company.

FERRARI, G. R. F. 2003. City and Soul in Plato's Republic. Chicago: University of Chicago Press. 
LEAR, J. 2006. “Allegory and Myth in Plato's Republic”. In: SANTAS, G. The Blackwell Guide to Plato's Republic. Chicago: Univ. Chicago Press.

PLATÃO. 2006. A República. Trad. Anna Lia Amaral de Almeida Prado. São Paulo: Martins Fontes.

VEGETTI, M. 1998. La Repubblica, vol. II - Libri II e III. Napoli: Bibliopolis.

XENOFONTE. 1997. Memorabilia - Oeconomicus - Symposium Apology. Trad. E. C. Marchant. Cambridge/London: Harvard University Press. 